ratio may well determine the resulting Hubble spiral class by influencing the formation of spiral structure and star formation rates in the disk. The exact conditions required for the presence of a bar remain rather obscure.

These interesting dynamical models have been investigated over only a very small number of possible parameter variations, and other variables still deserve investigation for their possible effect on the final morphological type. This model implies that the era of galaxy formation occurred at a redshift of about three, beyond which only quasars have yet been observed. This work may show that it is futile to attempt to understand the formation process without taking account of the dynamical effects of the dark matter.

M.G. Edmunds is in the Department of Physics, University of Wales College of Cardiff, $P O B$ Box 913, Cardiff $C F 13 T H, U K$.

\title{
Cell growth factors
}

\section{Bicarbonate and $\mathrm{pH}_{\mathrm{i}}$ response}

\section{Roger C. Thomas}

Much interest was aroused a few years ago by the first report ${ }^{1}$ of continuous recording of the intracellular $\mathrm{pH}\left(\mathrm{pH}_{\mathrm{i}}\right)$ response to growth factors in cultured fibroblasts. That the fibroblasts came from human foreskins (sic) caused some twinges, but the main interest was the possiblity that growth factors might stimulate growth, at least in part, by increasing $\mathrm{pH}_{i}$. Moolenaar and his colleagues ${ }^{\prime}$ showed that the $\mathrm{pH}_{\mathrm{i}}$ increase was caused by stimulation of $\mathrm{Na}-\mathrm{H}$ exchange, and later ${ }^{2}$ that protein kinase $\mathrm{C}$ activation was an intermediate step. But these experiments were done in the absence of bicarbonate, as pointed out at the time in a News and Views article by Boron ${ }^{3}$. On page 648 of this issue ${ }^{4}$, Boron and his colleagues now show that the growth factor arginine-vasopressin stimulates $\mathrm{HCO}_{3}$ transport more than it stimulates $\mathrm{Na}-\mathrm{H}$ exchange. This result explains the earlier report ${ }^{5}$ that in solutions containing $\mathrm{HCO}_{3}$ and $\mathrm{CO}_{2}$, there is not only no $\mathrm{pH}_{\mathrm{i}}$ increase, but the opposite happens $-\mathrm{pH}_{\mathrm{i}}$ decreases.

Boron's group has recently shown ${ }^{6}$ that there are three distinct $\mathrm{pH}_{\mathrm{i}}$ regulating mechanisms in the renal mesangial cells (related to smooth muscle) which they study (see figure). The first $\mathrm{Na}-\mathrm{H}$ exchange appears to be the main mechanism for extruding acid from mammalian skeletal muscle ${ }^{7}$, and was until recently thought to be the main mechanism for acid extrusion in all mammalian cells. The second, sodium-dependent $\mathrm{Cl}-\mathrm{HCO}_{3}$ exchange, was first identified in squid axons (but without the sodium dependence ${ }^{8}$ ) and later found in snail neurons", other invertebrate preparations ${ }^{10}$ and various vertebrate preparations ${ }^{11-13}$. The third mechanism, as first described in cardiac muscle by Vaughan-Jones ${ }^{14}$, is one for alkali extrusion - to accelerate recovery from an alkaline load. This mechanism is simple $\mathrm{Cl}-\mathrm{HCO}_{3}$ exchange, as is also found in red blood cells where it is responsible for the Hamburger interchange or chloride shift. (There is in some preparations a fourth mechanism, $\mathrm{Na}-\mathrm{HCO}_{3}$ co-transport, but mercifully it does not concern us here. Because Boron and colleagues in their latest studies did not record membrane potentials ${ }^{4}$, they may have missed evidence for this electrogenic carrier.) The three mechanisms shown in the figure have not hitherto been identified all in one cell type, as far as I know. The only mechanism known to work without bicarbonate is $\mathrm{Na}-\mathrm{H}$ exchange, inhibited specifically

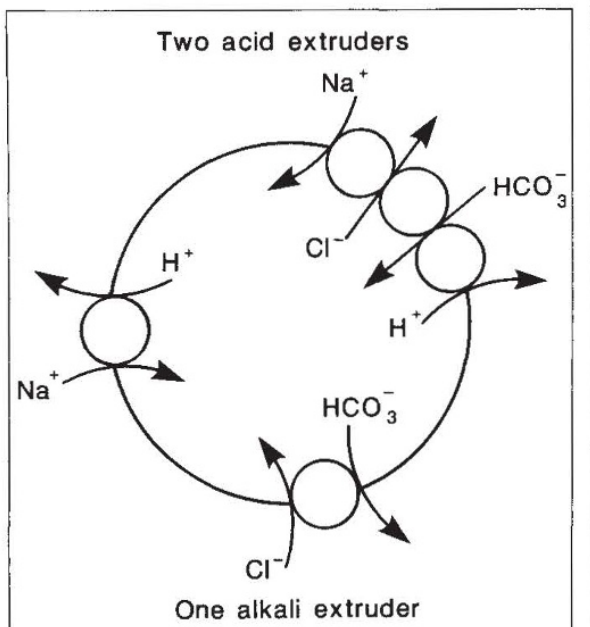

Ionic mechanisms involved in $\mathrm{pH}_{i}$ regulation in renal mesangial cells in the presence of bicarbonate.

by amiloride and related compounds.

Given that growth factors stimulate $\mathrm{Na}-\mathrm{H}$ exchange it might seem unlikely that they would also stimulate the two bicarbonate-requiring mechanisms in renal mesangial cells. But Boron and his co-workers clearly show ${ }^{+}$that all three mechanisms are stimulated. The dominant mechanism after stimulation is the alkali-extruding one. Thus the $\mathrm{pH}_{\mathrm{i}}$ increase seen with growth factor in the absence of bicarbonate is under physiological conditions a $\mathrm{pH}_{i}$ decrease. Clearly, the $\mathrm{Na}-\mathrm{H}$ exchanger is unlikely to be the transmembrane signal transducer originally proposed'.

Why was the possible importance of bicarbonate ignored for so long? Its crucial role in $\mathrm{pH}$ homoeostasis in the intact animal has long been recognized, if poorly understood by most students. Inside cells, it is often the most common anion, and outside it is the second most common after chloride. But in practice, bicarbonatebuffered solutions are difficult to handle. For a stable $\mathrm{pH}$ the solution must be equilibrated with a gas mixture containing a known and fixed percentage of $\mathrm{CO}_{2}$. Such gas mixtures are expensive and tend to vary from cylinder to cylinder. Carbon dioxide readily crosses plastic, especially silicone rubber tubing and leaves solution all too readily when pumped by a peristatic pump, for example. In many optical systems it is simply much easier to avoid any gas at all.

Thus, when it was discovered that cultured mammalian cells could regulate their $\mathrm{pH}_{\mathrm{i}}$ perfectly well with an amiloridesensitive $\mathrm{Na}-\mathrm{H}$ exchanger, it was widely assumed that bicarbonate would make no real difference. This assumption ignored the significance of bicarbonate in intracellular buffering ${ }^{10,15}$, even without taking into account its requirement by $\mathrm{pH}_{\mathrm{i}}$ regulators. Because the membrane is very permeable to $\mathrm{CO}_{2}$, intracellular carbonic acid concentration is effectively clamped. Thus every intracellular bicarbonation can buffer four times better at any physiological $\mathrm{pH}$ than any ordinary buffer at its pK. For fast buffering, carbonic anhydrase is needed ${ }^{16}$. The lack of bicarbonate in the original experiment would thus have exaggerated any $\mathrm{pH}_{i}$ change due to stimulation of $\mathrm{Na}-\mathrm{H}$ exchange.

There are two conclusions from this story. Intracellular $\mathrm{pH}$ is probably too fundamental a parameter to act as an intracellular messenger, even for an event as important as the initiation of growth except perhaps in acid-transporting epithelia ${ }^{17}$. As Boron has pointed out ${ }^{3}$, it is to be expected that growth factors will stimulate the housekeeping abilities of the cell such as $\mathrm{pH}_{\mathrm{i}}$ regulation, in anticipation of the increased metabolic requirement of growth. The second conclusion is that he who works in bicarbonate-free media risks studying cellular and molecular pathology rather than physiology.

. Moolenaar, W. H., Tsien. R. Y.. van der Saag. P. T. \& de Laat. S. W. Nature 304. 645 (1983)

Moolenaar, W. H. Tertoolen, L. G. J. \& de Laat. S. W. Nature 312, 371 (1984).

$312.312(1984)$

3. Boron, W. F. Nalure 312,312 (1984). (1989)

Cassel. D. et al. J. cell. Physiol. 122, 178 (1985)

Boyarsky, G.et al. Am. J. Physiol. 255. C844; C856 (1988)

. Aickin, C. C. \& Thomas, R. C. J. Physiol., Lond. 273. 295 (1986)

Russell, J. M. \& Boron, W. F. Nanure 264. 73 (1986)

Thomas. R. C. J. Physiol., Lond. 273. 317 (1977).

10. Roos. A. \& Boron, W. F. Physiol. Rev. 61.296 (1981)

L.Allemain, G. et al. J. biol. chem. 260. 4877 (1985)

Chesler. M. J. Physiol. Lond. 381, 241 (1986).

Ciba Fdn Symp. 139 (Wiley. Chichester, 1988)

4. Vaughan-Jones. R. D. (1982). In Intracellular $\mathrm{pH}$ (eds Nuccitelli, R. \& Deamer. D. W.) 239 (Liss. New York. 1982)

Szatkowski. M. S. J. Phvsiol., Lond. 409. 103 (1989)

6. Thomis. R C J Physiol Lond 354.3p (1984).

7. Harvey. B. J. et al. J. gen. Phvsiol. 92. 767 (1988)

Roger C. Thomas is in the Department of Physiology, University of Bristol, Bristol BS8 ITD, UK. 